\title{
Political Philosophy around Pandemic, or Vice Versa?*
}

\author{
NIKER F., BHATTACHARYA A. (EDS.) (2021) POLITICAL PHILOSOPHY IN A PANDEMIC: ROUTES TO A MORE JUST \\ FUTURE. LONDON: BLOOMSBURY ACADEMIC. 296 P. ISBN 9781-3502-2589-3

\section{Elizaveta Zakharova} \\ Research Assistant, Laboratory for Political Geography and Contemporary Geopolitics, HSE University \\ Address: Myasnitskaya str., 20, Moscow, Russian Federation 101000 \\ E-mail: eszakharova@hse.ru
}

The COVID-19 pandemic arose quickly, brought about devastating consequences for the whole planet, and posed the task to re-evaluate our beliefs and everyday habits. Being more than a mere health scare and more than a mere social malady, it exposed us to the need of revisiting our fundamental understanding of our way of life. The whole world sunk into a mysterious atmosphere of the unknown, thus raising new and uncommon questions that no one could answer. No one knew how to react, what to think of the disease and its consequences, how to provide observations, or how to draw conclusions. In this light, political philosophy is often chastised for addressing "perennial" problems while avoiding an analysis of contemporary issues; the book Political Philosophy in a Pandemic: Routes to a More Just Future tries to refute this belief by offering a mode of thinking as well as speaking of COVID-19 from a relevant standpoint.

Aveek Bhattacharya and Fay Niker have published a collection of essays on social welfare and vulnerability, economic justice, democratic relations, speech and (mis)information, crisis, and justice, topics quite common for political philosophy in 2021. The series of reflections starts with the publications on justice-everywhere.org, a blog about philosophy in public affairs which the editors help run (1). They are confident that the issues posed in the book and the results obtained are both unpredictable and predictable. On the one hand, some of them are easy to predict since the crisis has severely sharpened the problems of injustice, i.e. the poor condition of public health systems, educational and intergenerational inequalities, housing disadvantages, etc., all of which existed well before the pandemic. On the other hand, the virus has caused some fundamental changes in the collective behavior that were hardly predictable in the pre-pandemic era. In any case, all of these questions are related to the long-standing problems of political philosophy in one way or another, so the task of the volume reviewed is to highlight these manifold relationships from different conceptual angles. Borrowing classic ideas from political philosophy, it dares to extend their applicability well beyond purely academic matters, as nearly every scholar in the fields of the social sciences and the humanities has been trying to do after the onset of the pandemic. ${ }^{1}$ Nevertheless, the editors argue that their volume does not

* The results of the project "Ethics of Solidarity and the Biopolitics of Quarantine: Theoretical Problems of the Cultural and Political Transformations during Pandemic", carried out within the framework of the Basic Research Program at the National Research University Higher School of Economics (HSE University) in 2021, are presented in this work. 
claim to comprehensiveness in its coverage of the moral and political philosophy of the pandemic (3).

In any case, it is still unclear yet how philosophers should think about events like the pandemic. As the title suggests, the book is divided into five parts according to their topics: (1) social welfare and vulnerability; (2) economic justice; (3) democratic relations; (4) speech and (mis)information; and (5) crisis and justice.

The volume starts from the "Social Welfare" section, uncovering issues of policy analysis rather than of political philosophy. If we pay more attention to these chapters, we will find essays on the relations between the social determinants of public health and the concepts of risk and corrosive disadvantage (13), on children's vulnerability during school closures (43-50), as well as on the right to adequate housing (55-64). The language and methods of some chapters $(2,5)$ remind us first of public policy analysis, as well as of political science in general.

The evidence for this is quite obvious. The chapter written by Jonathan Wolff and Avner de-Shalit that is devoted to COVID's effect on the deficits in different domains and their interdependence is more of policy analysis, as we may see by the questions raised and the notions and methods used (e.g., "corrosive disadvantage", and "inverse crosscategory risk"). The authors based their research on the conception of well-being that matters more for policy analysis than for classical political philosophy today, since it is regarded "... not as a deep philosophical theory but as an operational concept" (15). The problem of the harm caused by the virus is raised in quite philosophical terms, but the conceptual tools are taken from policy analysis. I would not consider this as a significant flaw, as it makes it clear why the editors chose to open the book on political philosophy and pandemics in this way.

Chapter 3, written by Sara Van Goozen, raises more philosophical questions of utilitarianism, moral philosophy, and consequentialism (who should get the medical care first during a pandemic?). She tries to show how resources should be equitably distributed in the face of scarcity. Here, we find a mixture of policy analysis (general framework, and the division of citizens into categories), political philosophy (justice, value, and equality), and sociological (ranking, and models) languages. The significant philosophical advantage of the chapter is its attitude towards the material researched, since the author claims that her goal is to find multiple approaches by combining various theories. Thus, the conclusion that all those whose instrumental social value in terms of fighting the virus (such as medical workers, research scientists, or delivery drivers) is higher than others and should be given priority in receiving the medical treatment and care sounds very profound and promising, not because of its uniqueness, but because of the compelling evidence it relies on (39).

School closures during the lockdowns, which are depicted quite vividly in the next chapter written by Nicolás Brando and Katarina Pitasse Fragoso, are also presented rather in terms of policy analysis (i.e., what should professionals and parents do with their chil-

1. They want to show and "explore the relationship between crisis and opportunity to set out routes to a more just world after the pandemic" (2). 
dren's well-being and schooling problems?). The methodology and the practical results (the shift to online education) remain rather within the frame of political science than political philosophy, since online education in schools after the crisis is regarded as a prospect for inequality that will affect the least-advantaged children (50).

The chapter on housing, written by David Jenkins, Katy Wells, and Kimberly Brownlee, explores the tension between adequate and inadequate housing by investigating this divide in the context of lockdowns. Concerning the British statistics, that is, a quantitative analysis of the situation in the UK here and now, it matters whether or not a British citizen lives in inadequate housing, how this "inadequacy" could be classified further, and what kind of practical consequences we can get. An in-depth look at existing vulnerabilities is presented here. Some of the issues in this chapter sound as if they were within the framework of political philosophy, but the conclusions on social welfare do not resemble a philosophical reflection due to their obvious practical orientation (64-65). The language and methods of this part of the volume remind us rather of political science and policy analysis, while the research problems and the questions raised (not by the methods used but by their general meaning) relate more to political philosophy. It is safe to assume that the book is a step towards redesigning and advancing political philosophy to prepare it for research within the subject area of the social sciences.

The second part of the book on economic justice makes some relative philosophical contributions to the political sphere, but focuses more on economic and public policy challenges as they were formulated before the virus spread across the planet. The chapters by David Yarrow, Lisa Herzog, and Diana Popescu are mutually related, and share a common diagnosis of welfare states via a cross-country analysis. David Yarrow explores the problem of public debt, that is, how and by whom it should be paid for during the pandemic. His analysis, based on lucky egalitarian intuitions, aims to demonstrate that current COVID-related social vulnerabilities which hit the younger generations the most are the result of a long-term governmental policy directed at dismantling a welfare state, a general trend that needs to be reversed (80). Lisa Herzog discusses the state's obligations and social protection measures during the pandemic, advocating a return to the principle of comprehensive social insurance (91). Diana Popescu regards the welfare state as quite an inadequate place for the current challenges in proposing a regime of social solidarity that would involve a universal basic income for every citizen (93). All of the research presented in the chapter provides profound conclusions on the pandemic crisis. Why are things like this now? It is because of the privatization and individualization corrupting modern welfare states, and the decline of social insurance principles or a lack of social solidarity. The authors' frameworks assume the methods of economic and social sciences are already built into it, but it also retains the possibility to ask questions within the field of political philosophy. Perhaps the boundaries of such questions would be worth broadening by paying less attention to the "framework" itself. While the borders between the disciplines are not always distinct, the volume's authors' contributions are quite significant regarding the difficulty of compounding an original hypothesis into a step-by-step analysis. 
In Part III, devoted to democratic relations, a bright Chapter 11 written by Alexandru Volacu explores the "electoral trilemma" faced by the societies during the COVID-19 crisis (138). Volacu shows it to be an unbelievably dreadful task for an election to get through the pandemic as it demolishes its fundamental principles (i.e., electoral justice). The language and the whole point of the chapter demonstrate a high degree of coherence within the perspective of political philosophy, since elections are regarded here not as a standard governance procedure as political science does, but from the point of view of electoral justice and its consequences for the collective well-being.

One of the most philosophically-sophisticated chapters in Part IV that is devoted to "speech and misinformation" is Chapter 14 written by Rebecca Lowe. It is about the democratic states' obligations of transparency in times of crisis, and it raises the philosophical question "In which cases is a state-practiced non-transparency justifiable?" The chapter focuses on governmental speech, in particular whether, as some argue, the democratic state's obligation to transparency is lessened in crisis. The references to morality, to freedom in such conditions, and the fact that there cannot be one correct decision relates to political philosophy. Lowe presents a framework for the justification for non-transparency applying to COVID-19 via the case of mask-wearing (185). The philosophical dilemma not only highlights the problem, but also proposes some answers for liberal democratic societies. Here, we can see the link between theory and practice. Philosophy and political science are more straightforward as their language and conceptual tools are quite common for both, and might be shared.

The chapter on freedom of speech written by Jeffrey Howard starts by describing the current state of affairs, then discusses how can we speak (or write on social media) in public during COVID-19. Media misinformation concerning the virus affects freedom of speech. The author worries about communicative restrictions, asking what they may be. The critical problem for the author is that the government may come up with restrictions of practically any type (especially during the pandemic) since there is no moral protection of the right to free speech for virus-related misinformation (174).

The last chapter, which should have served as an opening for the book, is titled "Pandemic as Political Theory" (257). It turns the book's logic and title upside down. The volume is an attempt to answer the questions that the pandemic has raised in a general (as editors see it) framework of political philosophy: what are the borders of adequate/ inadequate housing; how should a welfare state operate effectively in the current crisis; if a democratic state falling into a state of emergency need to be transparent; and, can misinformation in the media be considered as freedom of speech or should it be subjected to restrictions. The pandemic is becoming a theory, while the tool turns out to be the subject. It has become a unifying context for all profound cases and objects to which all the notions and instruments of social sciences should have corresponded to.

From a broad perspective, the book makes a profound and very up-to-date contribution to the number of attempts interpreting the current state of affairs by observing the COVID-19 pandemic through the theoretical lens of contemporary social and political sciences. The book presents both empirical challenges concerning the virus and techni- 
cal challenges about immediate pandemic responses, attempting to maintain some continuity between the difficulties and challenges faced by contemporary societies in the pre-pandemic era. The authors and editors made many contributions to pronounce and formulate the language of speaking about pandemics, finding the best concepts, terms, and methods to get some reflections adequate to the situation. Crisis robs us of opportunities and exposes our dark flaws. However, the question of why this book is framed within political philosophy and not political science is still relevant; it also demonstrates quite vividly that today it seems reasonable to look at COVID issues in social sciences through a lens of political philosophy. It is about transforming the language and widening the boundaries of political philosophy.

Furthermore, the book is worth reading if the question of how to make the most of this [pandemic] moment of potential change before it vanishes remains among our priorities. If a question of the type "why and what is it for?" is asked, the maximum of conceptual recourses have to be raised. In addition, a lot of evidence will have to be gathered and accumulated in order to move forward. As time passes, many of the consequences and conclusions provided in the articles can become a framework or the tools for a new political philosophy design since its fundamental notions are going to be transformed with regard to the pandemic's dictionary and context. In the meantime, it is a prospect rather than a current state of affairs, but there is no doubt that political philosophy will investigate and understand the pandemic with the help of this book's contributions.

\title{
Политическая философия вокруг пандемии или пандемия вокруг политической философии?
}

\author{
Елизавета Захарова \\ Стажер-исследователь, научно-учебная лаборатория политической географии и современной \\ геополитики, Национальный исследовательский университет «Высшая школа экономики» \\ Адрес: ул. Мясницкая, д. 20, г. Москва, Российская Федерация 101000 \\ E-mail: eszakharova@hse.ru
}

Рецензия на: Fay Niker, Aveek Bhattacharya (eds.). Political Philosophy in a Pandemic: Routes to a More Just Future (London: Bloomsbury Academic, 2021). 